\title{
Etiological treatment of young women infected with Trypanosoma cruzi, and prevention of congenital transmission
}

\author{
Tratamento etiológico de mulheres jovens infectadas com \\ Trypanosoma cruzi e prevenção da transmissão congênita
}

\author{
Sergio Sosa-Estani ${ }^{1,2,3}$, Estela Cura ${ }^{4}$, Elsa Velazquez, \\ Cristina Yampotis ${ }^{6}$ and Elsa Leonor Segura ${ }^{3,5}$
}

\begin{abstract}
The objective was to detect Trypanosoma cruzi infection in 32 children in Salta, Argentina, born to 16 chronically infected young women who were treated with benznidazole. Tests were performed to assess the efficacy of treatment after 14 years. At the end of the follow up, $87.5 \%$ of the women were non-reactive to EIA tests, $62.5 \%$ to IHA and $43.8 \%$ to IFA. $62.5 \%$ of the women were non-reactive according to two or three serological tests. No infected children were detected among the newborns of mothers treated before their pregnancy.
\end{abstract}

Key-words: Trypanosoma cruzi. Chagas disease. Treatment. Congenital transmission. Prevention.

\section{RESUMO}

O objetivo foi detectar a infecção do Trypanosoma cruzi em 32 crianças nacidas de 16 jovens mulheres cronicamente infectadas e tratadas com benzinadol, em Salta, Argentina. Testes foram feitos para avaliar a eficácia após 14 anos do tratamento. Ao final do seguimento 87.5\% das mulheres foram não reativas ao EIA, $62.5 \%$ ao IHA e $43.8 \%$ ao IFA. $62.5 \%$ das mulheres foram não reativas de acordo a 3 ou 2 testes serológicos. Nenhuma criança infectada foi detectada entre os recém-nascidos de mães tratadas antes da gravidez.

Palavras-chaves: Trypanosoma cruzi. Doença de Chagas. Tratamento. Transmissão congênita. Prevenção.

Chagas disease, or American trypanosomiasis, is caused by the protozoan parasite Trypanosoma cruzi. It is a major cause of morbidity and mortality in Latin America. Infection is transmitted mainly by vectors but also congenitally and by transfusion of infected blood.

Specific treatment with benznidazole ${ }^{\circledR} 5-7 \mathrm{mg} / \mathrm{kg} /$ day for 60 days proved effective among children aged 6 to 12 years during the chronic phase of Trypanosoma cruzi infection ${ }^{1323}$. The goals of specific treatment against Trypanosoma cruzi infection are to eliminate the parasite from infected individuals, to decrease the chances of developing the illness (Chagas disease) and to

1. Centro Nacional de Diagnóstico e Investigación de Endemo-epidemias Administración Nacional de Laboratorios e Institutos de Salud "Dr. Carlos G. Malbrán, Buenos Aires, Argentina. 2. Instituto de Efectividad Clínica y Sanitaria, Buenos Aires, Argentina. 3. Consejo Nacional de Investigaciones Científicas y Técnicas, Argentina. 4. Centro Nacional de Control de Calidad de Biológicos/ANLIS, Buenos Aires, Argentina. 5. Instituto Nacional de Parasitología "Dr. Mario Fatala Chaben"/ANLIS, Buenos Aires, Argentina. 6. Hospital San Roque, Embarcación, Salta, Argentina.

Financial support: This project was partially supported by the Ministry of Health of Argentina, Ministry of Health of the Province of Salta, Argentina, and the Training and Research on Tropical Disease (TDR) UPND/WB/WHO/TDR Program.

Address to: Dr. Sergio Sosa-Estani. Centro Nacional de Diagnóstico e Investigación de Endemoepidemias (CeNDIE). Av. Paseo Colón 568 (1063), Buenos Aires, Argentina Tel: 5411 4331-4010; Fax: $54114331-2536$

e-mail: ssosa@msal.gov.ar

Received in 09/02/2009

Accepted in 28/08/2009 interrupt the chain of Trypanosoma cruzi transmission ${ }^{22}$. Focusing on interrupting the chain of transmission, the hypothesis is that etiological treatment of infected women of reproductive age may prevent congenital transmission. However, the most up-todate etiological treatment with currently available drugs is not recommended for pregnant women ${ }^{19}$. The objective of this study was to assess Trypanosoma cruzi infection among children born to women who were treated with benznidazole at young ages (6 to 15 years old). The information acquired will enable further evaluation of etiological treatments for preventing congenital Trypanosoma cruzi transmission.

\section{MATERIAL AND METHODS}

In this study, we assessed the presence of specific antiTrypanosoma cruzi antibodies and parasites in blood samples from women who received treatment when they were 6 to 15 years old and who were evaluated 14 years later. We also assessed the presence of specific Trypanosoma cruzi antibodies in their children older than nine months of age. We carried out a clinical observational study in eight villages in the Departments of Mosconi, San Martin and Oran in the north of the Province of Salta in Argentina. Women were treated with benznidazole $6 \mathrm{mg} / \mathrm{kg} / \mathrm{day}$ for 60 days in 1991, and were evaluated in 2005. Also in 2005, all 
children born to these women undergoing follow-up were studied by means of serological tests to detect specific T. cruzi antibodies. This area has been under continuous triatomine surveillance by sanitary agents since 1982 (i.e. they undertake regular insecticidal actions against infestations).

In 1991 and 2005, 8-10ml of maternal venous blood was obtained, and in 2005, $5 \mathrm{ml}$ of blood was obtained from their offspring. Whole blood samples $(1 \mathrm{ml})$ were stored with equal volumes of guanidine in order to perform the polymerase chain reaction (PCR), and serum was obtained by centrifugation. The serum was stored in two aliquots; one of them was frozen at $-70^{\circ} \mathrm{C}$ and the other one was stored with an equal volume of buffered glycerin. The samples with glycerin were later used for determining antibodies, when performing serological tests. We carried out an enzymatic immunoassay (EIA) ${ }^{11}$, an indirect hemagglutination assay (IHA) ${ }^{9}$, an indirect immunofluorescence assay (IFA) ${ }^{1}$ and an EIA using F29 antigen ${ }^{20}$. The guanidine-EDTA blood (GEB) mixture was stored at room temperature for the first seven days, and then at $4^{\circ} \mathrm{C}$ until DNA extraction ${ }^{2}{ }^{4}$. The PCR was performed following the technique described by Wincker et $\mathrm{al}^{28}$. Mothers were tested in 1991 and 2005 and their offspring were tested in 2005 with the same serological tests, under quality control ${ }^{12}$. The women were tested by means of xenodiagnosis in 2005 using four boxes, with 10 Triatoma infestans third or fourth-instar nymphs each ${ }^{10}$. All the tests were performed at the National Institute of Parasitology Dr. Mario Fatala Chaben in Buenos Aires, Argentina.

Descriptive data were presented as the prevalence with 95\% confidence interval (CI) when appropriate, or as means and standard deviations for continuous data. McNemar's tests of serological and molecular data were used to make comparisons of change of status of infection between before treatment and 14 years after treatment. The means were compared using the ANOVA and Mann-Whitney U-tests.
The results from the serological tests were shown as $\log _{2}$ of dilution of IHA (cutoff dilution $\geq 1 / 32$ ) and IFA (cutoff dilution $\geq 1 / 32$ ) and as absorbance of EIA (cutoff $\geq$ OD 0.200) and EIA-F29 (cutoff $\geq$ OD 0.170). The data analyses were done using Epi Info version 3.4 (CDC). This study was approved by CeNDIE committees, under the authority of the Minister of Health of Salta Province and the local hospitals of Pichanal, Embarcación and Gral. Mosconi. Informed consent to take samples was obtained from all women for themselves and their children. Signed informed consent for treatment of women in 1991, and oral informed consent were required for taking samples in 2005, in accordance with the current care guidelines for patients infected with Trypanosoma cruzi.

\section{RESULTS}

Sixteen women who had children during the 14 years of followup and 32 offspring were included in the study. The median age of the women was 26 years (ranging from 21 to 29 years of age). The median number of children studied per mother was two (ranging from one to four children). Four (25\%) mothers and eight (25\%) children were living in rural areas. No special antecedents of illness were recorded during physical examinations. The median age of the children was five years (ranging from 1 to 11 years of age) and the frequency of females among the children was 53.1\%. In 1991, all the mothers had at least two reactive serological tests, using EIA, HA and IFA, before treatment. Table 1 shows the results from the serological tests on the mothers in 1991 and 2005 and the results from tests on their children in 2005. Most of the serological techniques performed on the women showed high rates of negativization at the end of follow up, that is, 14 years after treatment. The rate of negativization was mainly in relation to EIA $(87.5 \%)$, EIA-F29 (77.8\%) and IHA (57.1\%). IFA shows a significant decrease in titers, although the rate of negativization (43.8\%) was not significant 14 years after

\section{TABLE 1}

Evolution of serological tests on women treated with benznidazole in 1991 and their children born during 144 months of follow-up. Salta, Argentina, 1991-2005.

\begin{tabular}{|c|c|c|c|c|c|c|c|c|c|c|c|c|c|}
\hline \multirow[b]{2}{*}{ Follow up } & \multicolumn{4}{|c|}{ EIA } & \multicolumn{3}{|c|}{ IHA } & \multicolumn{3}{|c|}{ IFA } & \multicolumn{3}{|c|}{ EIA F29 } \\
\hline & $\mathrm{n}$ & reactive & $\%$ & $P$ value & reactive & $\%$ & $P$ value & reactive & $\%$ & $P$ value & reactive & $\%$ & $P$ value \\
\hline \multicolumn{14}{|l|}{ Mothers } \\
\hline pre-treatment 1991 & 16 & 16 & 100.0 & & 14 & 87.5 & & 16 & 100.0 & & 9 & 69.2 & \\
\hline end of follow-up 2005 & 16 & 2 & 12.5 & 0.001 & 6 & 37.5 & 0.04 & 9 & 56.3 & 0.07 & 2 & 7.7 & $0.04^{*}$ \\
\hline \multicolumn{14}{|l|}{ Children } \\
\hline \multirow[t]{2}{*}{ controls 2005} & $32^{* * *}$ & 0 & 0.0 & $\mathrm{NA}$ & 0 & 0.0 & $\mathrm{NA}$ & 0 & 0.0 & $\mathrm{NA}$ & 0 & 0.0 & NA \\
\hline & & Mean & SD & P value & Mean & SD & P value & Mean & SD & P value & Mean & SD & P value \\
\hline \multicolumn{14}{|l|}{ Mothers } \\
\hline pre-treatment 1991 & 16 & 0.512 & 0.108 & & 7.4 & 3.2 & & 6.8 & 0.9 & & 0.291 & 0.218 & \\
\hline end of follow-up 2005 & 16 & 0.161 & 0.038 & $0.0001 \dagger$ & 3.1 & 2.7 & 0.0003 & 3.7 & 2.7 & $0.0001 \dagger$ & 0.105 & 0.048 & $0.02^{* * * *}$ \\
\hline
\end{tabular}

EIA: enzymatic immunoassay, IHA: indirect hemagglutination assay, IFA: indirect immunofluorescence assay, NA: not applicable, EIA: enzymatic immunoassay using F29 antigen.

* McNemar test was done with 13 samples matched in 1991 and 2005

*** One child was tested for EIA and IHA; both results were unreactive

**** Kruskal-Wallis test

$\dagger$ Serological tests on the mothers 1991-2005. Differences in proportions of reactive tests: EIA: $72.2 \%$ (95\% CI: 30.1-83.0); IHA: 41.2\% (95\% CI: 1.2-52.6); IFA: 33.3\% (95\% CI: -2.3-44.2); EIA-F29: 50.0\% (95\% CI: 2.2-63.9) 
treatment (Table 1). Final evidence of cure using serological criteria (three serological tests unreactive) was reached for six (37.5\%) women, while four (25\%) were discordant, with two tests non-reactive. None of the xenodiagnoses performed at the end of the follow-up were positive, although we found positive PCR results in two (12.5\%) mothers (Table 2). No differences were found regarding age or residence in a rural area between the women with two or three unreactive serological tests and the women with two or three reactive serological tests.

Among the 32 children under study, we did not find any evidence of congenital Trypanosoma cruzi infection (Table 1). No exposure to vectorial or transfusional transmission could be demonstrated, and other serological tests were unreactive. We used the most sensitive current technique for diagnosing congenital Trypanosoma cruzi transmission, which is the serological test in infants older than nine months of age $^{3717}$.

\section{TABLE 2}

Parasitological and molecular tests on mothers treated with benznidazole, Salta, Argentina, 1991-2005

\begin{tabular}{|c|c|c|c|c|c|c|c|}
\hline \multirow[b]{2}{*}{ Follow-up } & \multicolumn{4}{|c|}{ Xeno } & \multicolumn{3}{|c|}{ PCR } \\
\hline & $\mathrm{n}$ & positive & $\%$ & $P$ value & positive & $\%$ & $P$ value \\
\hline Pre-treatment 1991 & 12 & ND & - & - & 11 & 91.7 & \\
\hline End of follow-up 2005 & $16^{*}$ & 0 & 0.0 & $\mathrm{NA}$ & 2 & 12.5 & $0.02 * *$ \\
\hline
\end{tabular}

Xeno: xenodiagnosis, PCR: polymerase chain reaction, ND: not done, NA: not applicable.

* Total number of mothers with xenodiagnosis test $\mathrm{n}=15$.

** McNemar test was done with 12 samples matched in 1991 and 2005.

PCR on mothers 1991-2005. Differences in proportions of positive results: PCR: 61.5\% (95\% CI: 8.4).

\section{DISCUSSION}

Our results show the benefit of specific treatment for these women, who in most cases showed absence of parasitemia. The rate of positive xenodiagnosis among untreated patients who were infected during the chronic phase is expected to be between 30 to $50 \%$ for both adults and children ${ }^{1023}$. We and others ${ }^{15232527}$ have demonstrated that when patients are treated during the chronic phase of Trypanosoma cruzi infection and are cured, their antibodies disappear gradually and take several years to become definitively negative. Additionally, the time required to become negative differs depending on the test used ${ }^{23}$. On the other hand, consistent results have been observed among patients treated during the chronic phase, with evidence of absent or low parasitemia, even though antibodies were still present in the serum for a long term after treatment ${ }^{6} 810152325$.

Up until now, the benefit of specific treatment to clear or reduce parasitemia in infected populations, in order to prevent congenital transmission (one of the main non-vectorial means of transmission), had been hypothesized but never demonstrated.

The number of cases with congenital infection among this population was expected to be one or two cases, based on the rates of congenital infection recorded close to our study area, which have ranged from 4 to $13 \%^{5716182129}$, but not a single case was detected among the offspring of these mothers treated before pregnancy.
The low number of patients under observation did not allow us to measure the risk of transmission among reactive mothers: only two (12.5\%) mothers showed evidence of infection through positive PCR. It is known that reactive serological tests after treatment do not mean infection in all cases, and that discordance among tests after treatment suggests a degree of negativization during follow-up ${ }^{24}$. In the same way, no xenodiagnosis was positive after treatment, whereas at least $30 \%$ of xenodiagnoses are expected to be positive among adult patients with untreated chronic infection ${ }^{24}$. We can hypothesize that a positive effect regarding prevention of congenital transmission occurs in the population when at least $60 \%$ of the women treated before pregnancy show evidence of cure.

Our results support the concept that specific treatment for young women is useful at the level of secondary prevention because previously infected women were cured. Our results suggest that it is also helpful at the primary prevention level because such treatment would prevent congenital transmission. The main limitation of this study was its sample size and therefore an observation with a larger sample size will be necessary in order to confirm our finding. However, we do not have controls (untreated mothers) against which to measure the relative or absolute effect of the intervention for preventing congenital transmission. These limitations do not allow us to reach a final conclusion, but only to support the hypothesis.

For as long as appropriate drugs for use during pregnancy are not available, the alternative of treating young infected women or women of reproductive age (requiring contraceptive practices during the treatment) could be a highly effective strategy for preventing transmission of congenital Trypanosoma cruzi.

It is most important that we find timely methods for interrupting congenital transmission. After eliminating transmission by vectors and by blood transfusions, eliminating congenital Trypanosoma cruzi infection will be a critical final step in eradicating Chagas disease from large regions of Latin America.

\section{ACKNOWLEDGEMENTS}

We acknowledge the contributions of Drs. Pedro Flores (Director of the Hospital of Pichanal), Carlos Funes (Director of the Hospital San Roque of Embarcacion) and Mario Lazarte (Director of the Hospital Juan XXIII of Gral. Mosconi) and the technical assistance of Victor Vigil, Nilda Alonso, Pablo Fazio, Nestor Gallardo, Norma Andrada, Nora Mallagrino, Jose Ojea and the primary healthcare workers of the public hospitals of Embarcacion, Pichanal and Gral. Mosconi in Salta Province. Moreover, we would like to thank Dr. Jose Belizan for his helpful comments and Miriam Mlczoch for her help with editing.

\section{REFERENCES}

1. Alvarez M, Cerisola JA, Rohwedder RW. Immunofluorescence Test in The Diagnosis of Chagas' Diseases. Boletín Chileno de Parasitología 23: 4-8, 1968.

2. Avila HA, Sigman DS, Cohen LM, Millikan RC, Simpson L. Polymerase chain reaction amplification of Trypanosoma cruzi kinetoplast minicircle DNA isolated from whole blood lysates: Diagnosis of chronic Chagas' disease. Molecular and Biochemical Parasitology 48: 211-221, 1991. 
3. Blanco SB, Segura EL, Cura EN, Chuit R, Tulian L, Flores I, Garbarino G, Villalonga JF, Gurtler RE. Congenital transmission of Trypanosoma cruzi: An operational outline for detecting and treating infected infants in north-western Argentina. Tropical Medicine \& International Health 5: 293-301, 2000.

4. Britto C, Cardoso MA, Wincker P, Morel CM. A simple protocol for the physical cleavage of Trypanosoma cruzi kinetoplast DNA present in blood samples and its use in polymerase chain reaction (PCR)-based diagnosis of chronic Chagas' disease. Memórias do Instituto Oswaldo Cruz 88: 171-172, 1993.

5. Brutus L, Schneider D, Postigo J, Delgado W, Mollinedo S, Chippaux JP. Evidence of congenital transmission of Trypanosoma cruzi in a vector-free area of Bolivia. Transactions of the Royal Society of Tropical Medicine and Hygiene 101: 1159$1160,2007$.

6. Cancado JR. Long term evaluation of etiological treatment of Chagas' disease with benznidazole. Revista do Instituto de Medicina Tropical de São Paulo 44: 29-37, 2002

7. Carlier Y, Torrico F. Congenital infection with Trypanosoma cruzi: From mechanisms of transmission to strategies for diagnosis and control. Conclusions of round tables and synopsis of an international colloquium. Cochabamba, Bolivia, 6-8 November 2002, 2003. Available from: http://www.scielo.br/pdf/rsbmt/v36n6/ a24v36n6.pdf. Accessed 12/3/2007.

8. Castro AM, Luquetti AO, Rassi A, Chiari E, Galvao LM. Detection of parasitemia profiles by blood culture after treatment of human chronic Trypanosoma cruzi infection. Parasitology Research 99: 379-383, 2006.

9. Cerisola JA, Alvarez M, Martini GJW. Agglutination test using latex particles for the diagnosis of Chagas' disease. Medicina (Buenos Aires) 40 (suppl 1): 132-136, 1980.

10. Cerisola JA, Silva NN, Prata A, Schenone H, Rohwedder R. Evaluation of the efficacy of nifurtimox in chronic human chagasic infection by using xenodiagnosis (author's transl). Boletín Chileno de Parasitología 32: 51-62, 1977.

11. Cura EN, Ruiz AM, Velazquez E, Malagrino N, Orn A, Segura EL. Estandarización de un kit de confirmación (FATALAKIT) para el inmunodiagnóstico de la infección por el Trypanosoma cruzi. Medicina (Buenos Aires) 53: 82-90, 1993.

12. Cura EN, Segura EL. Quality assurance of the serologic diagnosis of Chagas' disease. Revista Panamericana de Salud Publica 3: 242-248, 1998.

13. De Andrade AL, Zicker F, Oliveira RM, Silva SA, Luquetti A, Travassos LR, Almeida IC, Andrade SS, Andrade JG, Martelli CM. Randomized trial of efficacy of benznidazole in treatment of early Trypanosoma cruzi infection. Lancet 348: 1407-1413, 1996.

14. Diez CN, Manattini S, Zanuttini JC, Bottasso 0, Marcipar I. The value of molecular studies for the diagnosis of congenital Chagas' disease in northeastern Argentina. The American Journal Tropical Medical and Hygiene 78: 624-627, 2008.

15. Fabbro DL, Streiger ML, Arias ED, Bizai ML, del Barco M, Amicone NA. Trypanocide treatment among adults with chronic Chagas' disease living in Santa Fe City (Argentina), over a mean follow-up of 21 years: Parasitological, serological and clinical evolution. Revista da Sociedade Brasileira de Medicina Tropical 40: $1-10,2007$
16. Gurtler RE, Segura EL, Cohen JE. Congenital transmission of Trypanosoma cruzi infection in Argentina. Emerging infectious diseases 9: 29-32, 2003.

17. Moya PR, Paolasso RD, Blanco S, Lapasset M, Sanmartino C, Basso B, Moretti E, Cura D. Treatment of Chagas' disease with nifurtimox during the first months of life. Medicina (Buenos Aires) 45: 553-558, 1985.

18. Negrette OS, Mora MC, Basombrio MA. High prevalence of congenital Trypanosoma cruzi infection and family clustering in Salta, Argentina. Pediatrics 115: e668-72, 2005.

19. Pan-American Health Organization. Etiological treatment for Chagas' disease: Conclusions of a technical consultation [in Spanish]. OPS/HCP/HCT/140/99 2008: p. 34, 1999.

20. Porcel BM, Bontempi EJ, Henriksson J, Rydaker M, Aslund L, Segura EL, Pettersson U, Ruiz AM. Trypanosoma rangeli and Trypanosoma cruzi: Molecular characterization of genes encoding putative calcium-binding proteins, highly conserved in trypanosomatids. Experimental Parasitology 84: 387-399, 1996.

21. Sosa-Estani S, Dri L, Touris C, Abalde S, Dell'arciprete A, Braunstein J. Vectorial and congenital transmission of Trypanosoma cruzi in Las Lomitas, Formosa. Medicina (B Aires), 2009

22. Sosa-Estani S, Segura EL. Etiological treatment in patients infected by Trypanosoma cruzi: Experiences in Argentina. Current opinion in infectious diseases 19: 583-587, 2006.

23. Sosa-Estani S, Segura EL, Ruiz AM, Velazquez E, Porcel BM, Yampotis C. Efficacy of chemotherapy with benznidazole in children in the indeterminate phase of Chagas' disease. The American Journal of Tropical Medicine and Hygiene 59: 526-529, 1998.

24. Sosa-Estani S, Viotti R, Segura EL. Therapy, diagnosis and prognosis of chronic Chagas disease: insight gained in Argentina. Memórias do Instituto Oswaldo Cruz 104: 167-180, 2009.

25. Streiger ML, del Barco ML, Fabbro DL, Arias ED, Amicone NA. Longitudinal study and specific chemotherapy in children with chronic Chagas' disease, residing in a low endemicity area of Argentina. Revista da Sociedade Brasileira de Medicina Tropical 37: 365-375, 2004.

26. Torrico F, Alonso-Vega C, Suarez E, Rodriguez P, Torrico MC, Dramaix M, Truyens C, Carlier Y. Maternal Trypanosoma cruzi infection, pregnancy outcome, morbidity, and mortality of congenitally infected and non-infected newborns in Bolivia. The American Journal of Tropical Medicine and Hygiene 70: 201-209, 2004.

27. Viotti R, Vigliano C, Lococo B, Bertocchi G, Petti M, Alvarez MG, Postan M, Armenti A. Long-term cardiac outcomes of treating chronic Chagas' disease with benznidazole versus no treatment: A nonrandomized trial. Annals of Internal Medicine 144: 724-734, 2006.

28. Wincker P, Britto C, Pereira JB, Cardoso MA, Oelemann W, Morel CM. Use of a simplified polymerase chain reaction procedure to detect Trypanosoma cruzi in blood samples from chronic chagasic patients in a rural endemic area. The American Journal of Tropical Medicine and Hygiene 51: 771-777, 1994.

29. Zaidenberg M. Congenital Chagas' disease in the province of Salta, Argentina, from 1980 to 1997. Revista da Sociedade Brasileira de Medicina Tropical 32: 689-695, 1999. 